\title{
Let the Games Begin
}

\section{Af Lasse Taagaard Jensen og Evald Iversen}

Historisk set er det ikke ofte sket, at danske politikere har vedtaget en lovgivning, der direkte har omhandlet idrætten. En undtagelse er dog vedtagelsen af eliteidrætslove i 1984 og 2004. Denne artikel vil beskæftige sig med spørgsmålet om, hvorvidt idrættens interesseorganisationer har været i stand til at påvirke den statslige lovgivningsproces i forbindelse med eliteidrætslovgivningen. Vi vil desuden belyse, hvad der er sket over tid med samspillet mellem stat og interesseorganisationer.

Artiklen skal dermed ses i forlængelse af Ivan Løvstrup og Jørn Hansens bog: $D a$ eliteidratten blev stueren (2002), der beskæftiger sig med den første eliteidrætslovs tilblivelse i 1984. Denne artikel placerer Løvstrups og Hansens analyse i en teoretisk ramme og anvender denne ramme til at analysere den seneste eliteidrætslovs tilblivelse i 2004.

Den teoretiske ramme, der opstilles nedenfor, betyder, at der primært er fokus på processen op til lovens vedtagelse, nemlig perioderne 1979-1984 og 2002-2004. Det betyder ikke, at det er uinteressant at beskæftige sig med lovgivningens konkrete indhold. Artiklen har imidlertid valgt at fokusere på lovgivningsprocessen frem for selve loven. Til gengæld vil vi her indledningsvist kort præsentere indholdet af den tidligere og nuværende eliteidrætslov.

Eliteidrætsloven fra 1984 førte til oprettelsen af en selvstændig institution. Denne skulle assistere med bl.a. rådgivning og individuel $\varnothing$ konomisk støtte i forhold til eliteidrætsudøvere over 15 år. Den nye selvstændige organisation, Team Danmark (TD), skulle ledes af et repræsentantskab og en bestyrelse. Repræsentantskabet fastlagde de overordnede retningslinier for organisationen og bestod bl.a. af repræsentanter for Danmarks Idræts-Forbund (DIF), DIF's specialforbund, Danmarks Olympiske Komite (DOK), trænere og aktive udøvere. Bestyrelsen bestod af syv medlemmer, hvoraf to var udpeget af Kulturministeren og fem af repræsentantskabet. Kulturministeren udpegede formanden blandt bestyrelsens medlemmer. ${ }^{1}$

Ifølge eliteidrætsloven fra 2004 skal eliteidrætsudøvere i alle aldersklasser støttes. Dertil kommer, at TD forpligter sig til en forsvarlig udvikling af eliteidrætsud$\emptyset$ veres fysiske, psykiske og sociale egenskaber. DIF er nævnt som den primære samarbejdspartner, og det understreges, at TD skal agere i samarbejde med DIF og DIF's specialforbund. I forhold til styringen af TD er det mest iøjnefaldende, at repræsentantskabet er blevet fjernet og erstattet af en bestyrelse. Det er nu Kulturministeren, der godkender TD's budgetter og regnskab i stedet for et repræsentantskab. ${ }^{2}$ Fire medlemmer udpeges af DIF, og fire medlemmer udpeges af Kulturministeren herunder formanden.

Som det fremgår af ovenstående, er der 


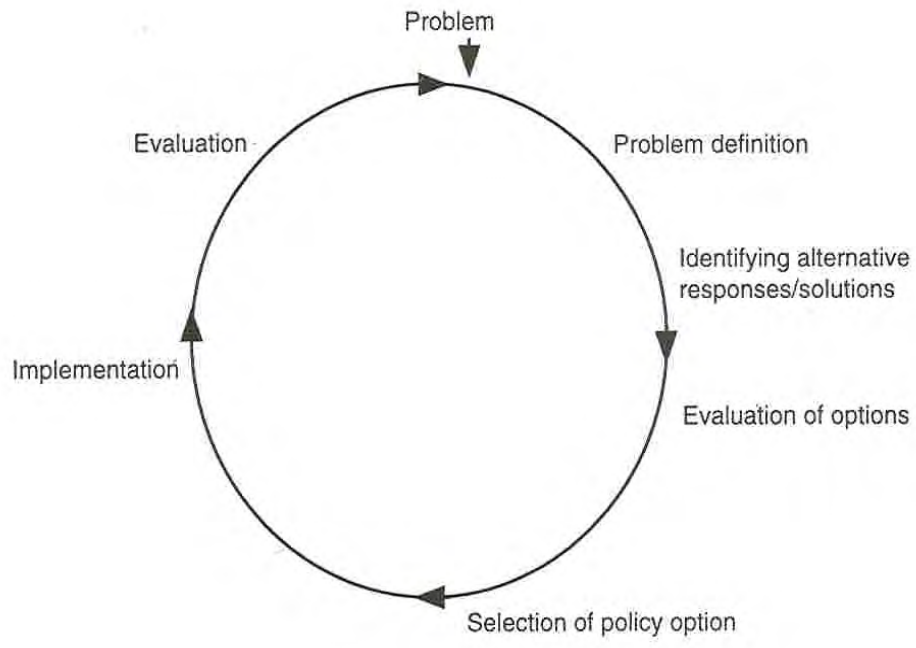

Figur 1. Parsons definition af en policanalyse.

sket forandringer på flere måder. Substansen - hvordan skal eliteidrætten støttes - er ændret, men også de styringsmæssige relationer er forandret. Det vil være et centralt argument i nedenstående analyse, at det er muligt at pege på forskelle i de to lovgivningsprocesser, men at det også er muligt at spore en $h ø j$ grad af kontinuitet i den måde, hvorpå de centrale aktører interagerer i eliteidrætsfeltet.

\section{En policyanalyse af eliteidroetslovgivningen}

Vi vil i det følgende analysere lovenes tilblivelseshistorie med afsæt i Wayne Parsons cykliske opfattelse af en policyproces, som er skitseret i figur $1 .^{3}$

Processen inddeles i faser, som alle beslutningsprocesser gennemløber. Opfattelsen er cyklisk forstået på den måde, at implementeringen og evalueringen af den vedtagne policy fører til at nye problemer opstår, hvorefter processen igen kan starte. En samlet analyse af en sådan cyklus indeholder derfor mange elementer, som det vil være for omfangsrigt at inddrage her. Vi vil derfor udelukkende se på den første del af policyprocessen. Det vil sige den del, der fokuserer på, hvordan problemet opstår, hvordan det defineres, hvordan policyalternativer formuleres, og endeligt hvordan der sker en udvælgelse blandt de definerede policymuligheder.

En sådan analyse fordrer en teoretisk tilgang, der fokuserer på den del af policyprocessen, som foregår før vedtagelsen, og således sætter fokus på andet end selve beslutningsprocessen i Folketinget. Derfor trækker vi i analysen på R.A.W. Rhodes policynetværksteori, ifølge hvilken det er muligt at analysere en politiks tilblivelse ud fra en vurdering af, hvordan samspillet mellem processens aktører er på forskellige dimensioner, som uddybes nedenfor.

Kildemæssigt baserer vi artiklen på ministerielle publikationer, tidsskriftsartikler og avisartikler. Dermed indfanges de uofficielle kontakter mellem stat og interesseorganisationer i forbindelse med telefonsamtaler, møder, festlige lejligheder osv. ikke. Dette metodiske forbehold vil fremover blive benævnt »black box«-problematikken, idet der vil være dele af den uformelle 


\begin{tabular}{|c|c|c|}
\hline Dimension & Politik fællesskab & Emne-netværk \\
\hline \multicolumn{3}{|l|}{ Medlemskab } \\
\hline Antal deltagere : & Begrænset antal & Mange deltagere \\
\hline Interessetype : & $\begin{array}{l}\text { Økonomiske og/eller professionelle } \\
\text { interesser dominerer }\end{array}$ & En række forskelligartede interesser \\
\hline \multicolumn{3}{|l|}{ Integration } \\
\hline Interaktions-frekvens : & $\begin{array}{l}\text { Hyppig interaktion med deltagelse af } \\
\text { alle grupper }\end{array}$ & $\begin{array}{l}\text { Interaktionen fluktuerer i frekvens og } \\
\text { hyppighed }\end{array}$ \\
\hline Kontinuitet : & $\begin{array}{l}\text { Medlemskab, værdier og outcomes } \\
\text { vedholdende over tid }\end{array}$ & Adgang fluktuerer betydeligt \\
\hline Konsensus : & $\begin{array}{l}\text { Alle deltager deler grundlæggende } \\
\text { værdier }\end{array}$ & Konflikt er altid til stede \\
\hline $\begin{array}{l}\text { Ressourcer } \\
\text { Fordeling af ressourcer inden for } \\
\text { netværket. }\end{array}$ & Alle deltagere besidder ressourcer & Deltagerne har begrænsede ressourcer \\
\hline Magt : & Magtbalance mellem medlemmerne & Ulige fordeling af magt \\
\hline
\end{tabular}

Figur 2. Forskellige typer af policynetvark.

lovgivningsproces, der forbliver i den blinde vinkel i vores analyse.

\section{Det teoretiske udgangspunkt}

Rhodes' definition af forskellige former for policynetværk anvendes her til at analysere samspillet mellem idrættens organisationer og staten. Staten er i denne sammenhæng primært Kulturministeriet, mens interesseorganisationerne er idrættens hovedorganisationer, i dette tilfælde særligt DIF. Denne tilgang skyldes, at vi arbejder ud fra et meso-niveau, hvor vi betragter de involverede organisationer som samlede enheder, der udadtil optræder med relativt klare og veldefinerede præferencer.

Det dynamiske samspil mellem stat og interesseorganisationer kan således betragtes som et policynetværk. Disse har forskellige karakteristika, som i kursorisk form er gengivet i nedenstående figur. ${ }^{4}$

Politikfællesskabet er præget af få aktører, der alle er i besiddelse af $\varnothing$ konomiske og/eller professionelle ressourcer. Der findes en vis konsensus mellem medlem- merne om de grundlæggende værdier i samarbejdet og en hyppig interaktion. Et emnenetværk er derimod præget af et mere flygtigt samarbejde. Der er mange medlemmer, som har divergerende interesser hvilket efterlader et vist konfliktpotentiale.

Ved at vurdere de ovennævnte dimensioner ved eliteidrætslovgivningen i 1984 og 2004 kan netværkstypen fastslås. Dernæst vil vi ved en sammenligning vurdere, om samspillet har ændret sig over tid. Samarbejdet mellem stat og interesseorganisation kan ifølge Rhodes beskrives på et kontinuum mellem et politikfælleskab og et emnenetværk.

Ud fra en identificering af netværkstype kan interesseorganisationernes påvirkning af processen vurderes. Hvis netværkstypen tenderer mod at være et politikfællesskab, har interesseorganisationer megen indflydelse på lovgivningsprocessen, mens det omvendte er tilfældet, hvis netværkstypen viser sig at tendere mod at være et emnenetværk. ${ }^{5}$ Første skridt bliver således en nærmere analyse af tilblivelsesprocessen i forbindelse med den første eliteidrætslov. 


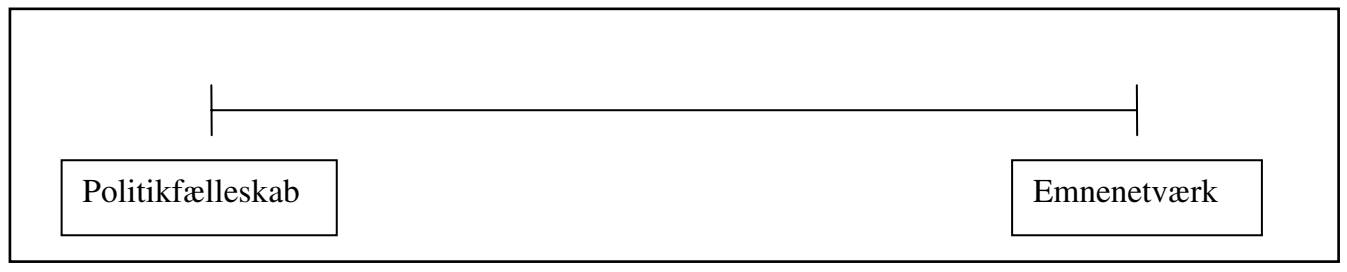

Figur 3. Illustration af kontinuum.

\section{Den forste eliteidratslovs tilblivelse}

Dårlige OL-resultater i 1972 og 1976 betød, at man fra politisk hold i 1977 var indstillet på at forbedre eliteidrættens forhold. ${ }^{6}$ Kulturminister Niels Matthiasen (S) nedsatte på den baggrund i 1979 et eliteidrætsudvalg bestående af repræsentanter fra bl.a. idrættens hovedorganisationer, trænere/ledere og aktive udøvere. I 1983 kom udvalget frem til et forslag om, at der skulle oprettes en selvejende institution til at fremme dansk eliteidræt. ${ }^{7}$ Udvalgets arbejde førte til vedtagelsen af en eliteidrætslov i december $1984 .{ }^{8}$ For at klargøre, hvilken form for policynetværk der var tale op, vil der i det følgende blive vurderet, hvordan de forskellige dimensioner af netværket udfolder sig i praksis.

\section{Netvarksanalyse af lovgivningsprocessen 1979-1984}

Ifølge Rhodes må vi i en policynetværksanalyse beskrive dimensionerne medlemskab, integration, ressource og magt med henblik på at afsøge, om der er tale om et politikfællesskab eller emnenetværk.

Medlemsskabsdimensionen kræver en vurdering af antallet af deltagere i netværket. Der er ikke enighed om, hvad der er årsag til udvalgets sammensætning. ${ }^{9}$ Men udvalget bestod af bl.a. DIF og flere af DIF's specialforbund, DOK, samt organisationer der i højere grad repræsenterer breddeidrætten (De Danske Gymnastik- og Ungdomsforeninger, De Danske Skytte, Gymnastik \& Idrætsforeninger og Dansk Firmaidrætsforbund). Udvalget kom også til at bestå af aktive udøvere, trænere og ledere. ${ }^{10}$ Hermed var eliteidrætsorganisationernes position i udvalget kompromitteret, hvilket betød, at betænkningen kom til at indeholde elementer, der ikke var i DIF's og DOK's interesse. ${ }^{11}$

I forhold til integrationsdimensionen er det bl.a. interaktionen mellem aktørerne, der skal belyses. DIF var ikke enig i alle eliteidrætsbetænkningens punkter, men organisationen blev den dominerende aktør fra betænkningens offentliggørelse i oktober 1983 frem til lovforslagets fremsættelse i oktober 1984. DIF var således inddraget i store dele af formuleringen af loven. Ministersekretær Claus Bøje udtaler i et interview, at »... der reelt skete dét, at sekretariatet for dansk idratspolitik $i$ den periode blev flyttet ud til DIF «. Samtykkende udtaler DIF's daværende generalsekretær Bent Agerskov, at han »...sad på sk $\phi$ det af Claus Bøje og skrev lovforslaget «12 Ved valget til TD's første bestyrelse fik både træner/leder gruppen og de aktive udøvere hver en repræsentant. DIF, DIF's special- 


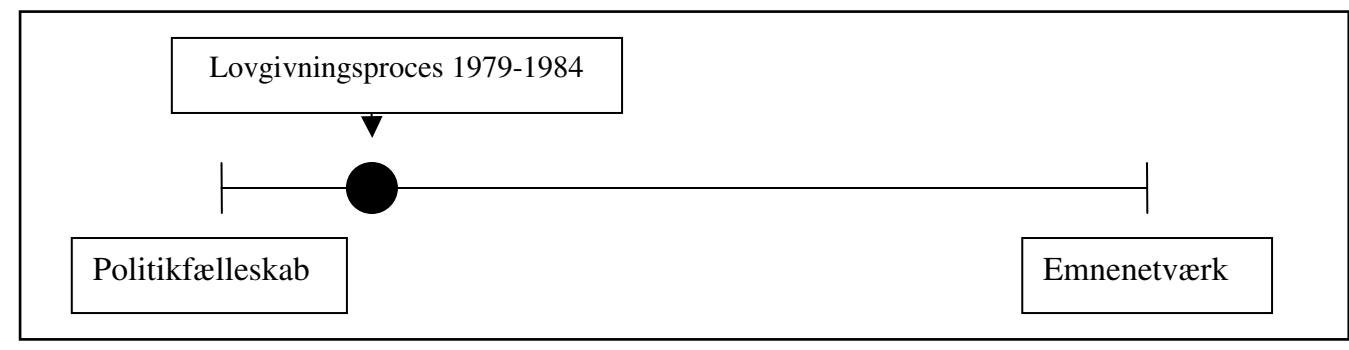

Figur 4. Placering af lovgivningsprocessen 1984.

forbund og DOK fik kun to repræsentanter tilsammen i bestyrelsen. Selv om DIF undervejs har været meget integreret i processen, blev dette ikke omsat til pladser i bestyrelsen. Men kulturminister Mimi Jakobsen udnævnte bl.a. Arne Garnell til sin repræsentant $i$ bestyrelsen. Han var formand for DOK og medlem af DIF's forretningsvalg, hvorfor udnævnelsen $\emptyset$ gede DIF's indflydelse. Frekvensen af interaktioner mellem stat og interesseorganisationer var $h ø j$, og der herskede en grad af konsensus mellem stat og interesseorganisationer, hvilket er et klassisk træk ved et politikfællesskab, hvor der findes »faelles opfattelser og vardier ${ }^{13}$

En kortfattet karakteristik af ressourcedimensionen synes også at tegne et mønster af et politikfællesskab. DIF besidder, som den overordnede paraplyorganisation for eliteidræt, faglig know-how. Staten har på den anden side de $\varnothing$ konomiske midler til oprettelsen af en eliteidrætsorganisation.

Magtforholdet mellem stat og interesseorganisationer kan være svært at belyse. Det tyder på, at DIF, som i det lovgivende arbejde har haft meget magt gennem sine tætte bånd til Kulturministeriet. Denne mulighed kan breddeidrættens organisationer ikke benytte sig af, men det kan formodes, at en eventuel konflikt over dette skæve styrkeforhold blev afværget ved, at der var blevet stillet en breddeidrætsbetænkning i vente. Styrkeprøven mellem staten og interesseorganisationerne faldt $\mathrm{i}$ den nye eliteidrætsinstitution TD ud til idrætsorganisationernes fordel. Staten udpegede således kun to ud af 24 medlemmer af repræsentantskabet og to medlemmer i bestyrelsen.

På baggrund af den ovenstående analyse er der altså flere ting, som tyder på, at der udviklede sig et politikfællesskab omkring eliteidrætslovgivningen i 1984. Antallet af aktører var begrænset, idet idrættens hovedorganisationer og staten dominerede lovgivningsarbejdet. Dialogen foregik i høj grad mellem disse parter uden indblanding fra andre aktører. Interaktionsfrekvensen synes at have været $h ø j$ mellem kulturministeren og DIF. Der var ligeledes mellem stat og interesseorganisationer konsensus om, at eliteidrætten skal støttes, uden at det sker på bekostning af bredden.

Der findes dog også træk ved lovgivningsprocessen, som peger mod et emnenetværk. De aktive blev inddraget i forarbejdet til lovgivningen og fik en plads i repræsentantskabet. Samlet må de aktives indflydelse dog vurderes til at være begrænset. Alt i alt tenderer samspillet mellem stat og interesseorganisationer i perioden fra 1979 til 1984 således mod at være et politikfællesskab. 
Spillet om en ny

eliteidratslovgivning tager sin begyndelse

Efter vedtagelsen af eliteidrætsloven i 1984 var der bortset fra enkelte efterdønninger en lang periode, hvor der ikke var planer om at revidere eliteidrætslovgivningen. Men i 1999 foreslog den radikale kulturminister, Elsebeth Gerner Nielsen, at den efterhånden 15 år gamle eliteidrætslov skulle revideres. ${ }^{14}$ Hun nedsatte en arbejdsgruppe, hvor både DIF og TD var repræsenteret.

Efter to år anbefalede arbejdsgruppen, at repræsentantskabets sammensætning og funktion blev ændret på en måde, der gjorde, at DIF fik mindsket indflydelse på TD. I sidste øjeblik valgte DIF's repræsentant at gå imod rapportens konklusioner. DIF underminerede dermed rapporten, hvilket forårsagede vrede fra de $\emptyset$ vrige medlemmer af arbejdsgruppen. DIF's direktør Karl Chr. Koch blev efterfølgende beskyldt for både at være en »underløber « og en »lurepasser $\ll .^{15}$

Elsebeth Gerner Nielsen tog alligevel positivt imod udvalgets konklusioner, mens den nytiltrådte kulturminister, Brian Mikkelsen (K), i begyndelsen af 2002 valgte at feje arbejdsgruppens konklusioner af bordet. Han ville hurtigst muligt starte processen på ny sammen med TD og DIF. ${ }^{16}$

\section{Den nye eliteidrcetslovs tilblivelse}

I september 2002 nedsatte Brian Mikkelsen et udvalg, hvor DIF og TD blev repræsenteret ved deres direktører henholdsvis Karl Chr. Koch og Preben Kragelund. Dertil kom kontorchef Søren Riiskjær fra Kulturministeriet samt formanden for ud- valget, amtsborgmester for Sønderjyllands Amt, Carl Holst (V). Endelig sad Dansk Boldspil Unions (DBU) formand og to aktive udøvere også i udvalget. Kerneopgaven bestod $i$ at finde frem til en fremtidig organisations- og finansieringsmodel for eliteidrætten i Danmark. ${ }^{17}$ I forhold til tidligere var sammensætningen vippet til DIF's side, da DBU var repræsenteret på bekostning af repræsentanter fra Institut for Idræt, Københavns Universitet og Claus Bøje, som var del af udvalget under Elsebeth Gerner Nielsen. Det er på baggrund af dette udvalgsarbejde, at den nuværende lovgivning er blevet til, hvorfor det er samspillet mellem udvalgets parter og staten, der vil blive analyseret nærmere nedenfor.

\section{En netvarksanalyse af lovgivningsprocessen 2002-2004}

For det første skal analysen afsøge medlemskabsdimensionen. Ved lovgivningsprocessen frem til den nuværende eliteidrætslov kom aktørerne i udvalget fra de mest oplagte interesseorganisationer blandt idrættens hovedorganisationer, og fra statens side var Kulturministeriet den centrale aktør. ${ }^{18}$ Det er muligt, at der findes kontakter, som er skjult jf. »black box« problematikken. Men den del af samspillet, vi har haft mulighed for at undersøge, er domineret af TD, DIF, Kulturministeriet og TD's Træner-Aktiv gruppe. Når parterne interagerer over en vis periode, virker det rimeligt at antage, at samspillet mellem disse organisationer og staten intensiveres, mens andre parter mere eller mindre ekskluderes. ${ }^{19}$ Der er trods alt tale om et begrænset antal aktører, hvilket peger i retning af et politikfællesskab. 
DIF's formand, Kai Holm, synes, at have et tæt forhold til kulturministeren, hvilket bl.a. ses ved, at den endelige lovgivning ikke fuldstændigt afspejler DIF's ønsker og krav - men det er tæt på. DIF undgår, at det specifikt nævnes i lovteksten, at trænere og aktive skal være repræsenteret; men kommer dog ikke igennem med kravet om, at TD lægges ind under DIF. ${ }^{20}$

For det andet skal integrationen i netværket analyseres. I dette tilfælde er interaktionen mellem parterne høj. Der afholdes i alt 12 møder i arbejdsgruppen, og det må desuden formodes, at de centrale aktører ${ }^{21}$ har en løbende kommunikation omkring potentialerne i lovgivningen. Men grundlæggende støder vi her endnu engang på »black box« problematikken.

Den interaktion, der umiddelbart er synlig, synes ikke at pege i retning af, at TD og DIF kommer specielt godt ud af det med hinanden. De forsøger i 2002 at oprette et »Idrættens Elitesportudvalg«, der skal fungere som et samarbejdsorgan mellem DIF og TD omkring eliteidræt. ${ }^{22}$ Udvalget bliver nedsat, men som et resultat af, at DIF arbejder med at få så stor indflydelse på TD’s fremtid som muligt, forværres klimaet i løbet af 2002 mellem DIF og TD, bl.a. fordi rådgivningsfirmaet KPMG på DIF's foranledning fremstiller en rapport, der anbefaler, at TD knyttes tættere til DIF. ${ }^{23}$ Der er dermed ikke noget, der peger på, at dette er opstarten til et nyt forbedret samarbejde mellem de to organisationer. ${ }^{24}$ Sagt med Rhodes' termer synes frekvensen af interaktionen nok at være høj-men det synes graden af konsensus derimod ikke at være. Grundlæggende deler deltagerne den opfattelse, at der skal vindes så mange guldmedaljer som muligt. Men hvor DIF ser det som hensigtsmæssigt, at statens styringsrelation forstærkes, ønsker TD sammen med specialforbundene i højere grad at opretholde status quo. ${ }^{25}$
Den tredje dimension i analysen af policynetværket gælder ressourceforholdet. TD, DIF og Kulturministeriet besidder alle betydelige ressourcer såvel økonomisk som vidensmæssigt. TD har et unikt kendskab til eliteidrætsudøveres vilkår, DIF et stort sekretariat og repræsenterer desuden specialforbundene, og kulturministeren har adgang til et ganske sikkert flertal i Folketinget sammen med Dansk Folkeparti. Til gengæld virker det mere problematisk for de aktive at yde kvalificeret modspil, hvad angår de administrative ressourcer. ${ }^{26}$

Med hensyn til den fjerde dimension synes der umiddelbart at være en magtbalance mellem medlemmerne. På den ene side er der ingen tvivl om, at DIF og TD besidder nogle organisatoriske ressourcer, som de søger at omsætte til reel indflydelse såvel i som udenfor udvalget. Men TD's Træner-Aktiv gruppe har andre ressourcer, der gør, at de også har en vis magt. I hvert fald formår de $\mathrm{i}$ forbindelse med høringen og den efterfølgende behandling i kulturudvalget at få fastholdt, at trænere skal være repræsenteret i TD's bestyrelse. Men det lykkes ikke at få nævnt dette krav i lovteksten, hvilket måske kan tilskrives, at hverken DIF eller DIF's syv største specialforbund $\varnothing$ nskede trænere repræsenteret $\mathrm{i}$ bestyrelsen. ${ }^{27}$ Til gengæld synes DIF's position at blive svækket af, at de syv største specialforbund melder ud, at det er deres $\emptyset$ nske, at TD videreføres i dets nuværende konstruktion. ${ }^{28}$ Trods alt synes Træner-Aktiv gruppen at have en god sag, idet det virker, som om det er vanskeligt for kulturministeren at overhøre det rimelige $i$, at trænere og aktive får indflydelse på deres egen fremtid.

Samlet set placeres netværkstypen tættere mod et emnenetværk, end det var tilfældet op til lovgivningen i 1984. Men der er fortsat tale om, at netværkstypen i højere 


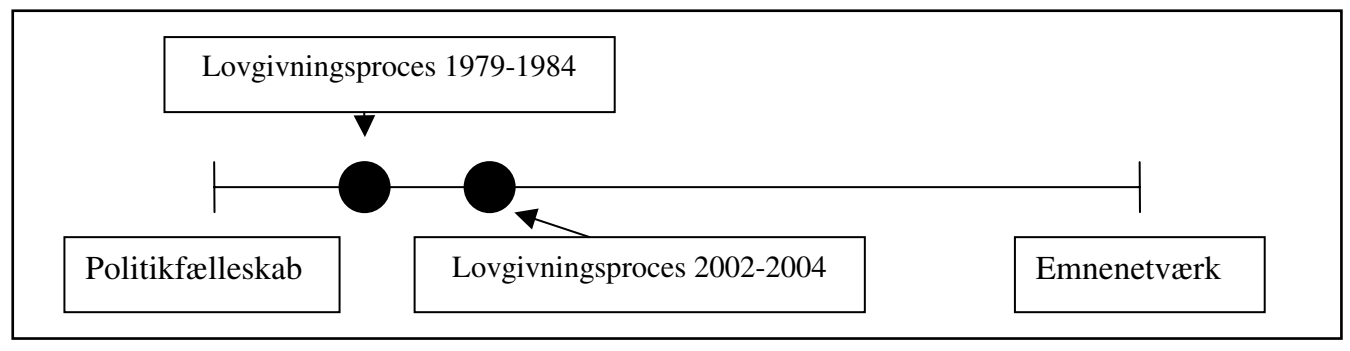

Figur 5. Placering af lovgivningsprocesen 2004.

grad tenderer mod at være et politikfællesskab. I det efterfølgende vil vi via sammenligning af de to lovgivningsprocesser $\mathrm{i}$ 1984 og 2004 argumentere for denne placering.

Sammenligning af vedtagelsen af eliteidratslovgivningen $i$ 1984 og 2004

For at komme nærmere en vurdering af policyprocessen i 1984 og 2004 sammenlignes de to forløb med afsæt i Rhodes' dimensioner. Ved en sammenligning bliver det også muligt nærmere at vurdere, hvad det konkret er, der har ændret sig i idrætsorganisationernes og statens samspil over tid.

Det, der mest af alt springer i øjnene, når man ser på de to forløb, er, at TD er en væsentlig med- og modspiller i processen i 2004, mens denne af naturlige grunde ikke var til stede i 1984. På medlemskabsdimensionen ses dette ved, at der er flere aktører i spil, og at disse grundlæggende repræsenterer flere forskellige interesser $\mathrm{i}$ 2004. TD har slået sit navn fast på DIF's bekostning, hvorfor DIF synes at have et $\varnothing n s k e$ om at genvinde noget af det tabte.

Der er både i 1984 og i 2004 en hyppig og kontinuerlig interaktion mellem parterne. Hjørnestenene i forhandlingsprocesser- ne imellem stat og interesseorganisationer i 1984 udgøres af DIF og Kulturministeriet; og i 2004 af DIF, TD og Kulturministeriet. Der var i 1984 enighed blandt stat og interesseorganisationer om, at eliteidrætten skulle statsstøttes, og at denne støtte ikke måtte gå ud over breddeidrætten. Den samme enighed var til stede i 2004 - men aktørerne var til gengæld uenige om, hvordan TD fremover skulle styres. Den væsentligste forskel var, at TD og Træner-Aktiv gruppen var på banen. Der er dermed en højere grad af konflikt.

Alle parter besidder ressourcer i såvel 1984 og 2004. Mens der i 1984 synes at være en klar hierarkisk fordeling, hvor DIF og Kulturministeriet er de dominerende parter, er billedet mere broget i 2004. TD bevarer sin status som en selvstændig institution, og trænere og aktive loves plads i bestyrelsen. Der er ikke tvivl om, at DIF og Kulturministeriet gennem lovgivningen i 2004 i højere grad opnår en styring af TD på grund af den nye bestyrelsessammensætning.

Samlet set tegner der sig et billede af, at samspillet mellem stat og interesseorganisationer er mindre forudsigeligt og mere konfliktfyldt i 2004. De dårlige relationer mellem DIF og TD spiller en væsentlig rolle, idet interesseorganisationerne dermed ikke har klart definerede præferencer over for staten. I stedet har der været tale om et 
trekantsdrama, hvor TD og TD's samarbejdspartnere, DIF og Kulturministeriet hver især forsøgte at komme igennem med sine ønsker.

I såvel 1984 som 2004 har DIF formået at spille en central rolle. I 1984 var organisationens indflydelse endnu mere markant end i 2004, idet man opnåede en næsten enerådig adgang til de centrale faser i lovgivningsprocessen, mens der i 2004 var flere forstyrrende elementer på banen; særligt TD og TD's Træner-Aktiv gruppe.

Idrættens organisationer er i forbindelse med begge eliteidrætslove i høj grad blevet inddraget $\mathrm{i}$ det lovforberedende arbejde. Der lyttes fra statens side til de involverede parters interesser i forbindelse med diverse høringsmuligheder, og disse forslag kan genfindes i lovforslaget. DIF formår i begge tilfælde at sætte sig i en gunstig position. Særligt i 2004 synes der dog også at være pluralistiske træk. Det vil sige, at flere parter høres. I alt høres således 31 parter i den lovforberedende fase. Dertil kommer henvendelser fra DIF, TD, TD's TrænerAktiv gruppe, de syv største specialforbund under DIF, Kommunernes Landsforening og Kulturudvalget. ${ }^{29}$ I 1984 var der et mere snævert parløb mellem kulturminister Mimi Jakobsen og idrættens topfolk. Hvor tæt samarbejdet var mellem Kai Holm og Brian Mikkelsen i 2004, kan vi kun gisne om. Men en mulig tolkning af forløbet er, at Kai Holm udnyttede de tætte kontakter til Brian Mikkelsen til at sikre sig en fordelagtig sammensætning af bestyrelsen.

\section{Konklusion}

Samlet set er der ingen tvivl om, at de danske idrætsorganisationer har formået at påvirke den lovgivning, der gennemføres på deres område. Men der er heller ikke no- gen tvivl om, at det øgede antal organisationer på området og idrættens stigende betydning i samfundet generelt har intensiveret opmærksomheden fra politisk hold. Det ses konkret i denne analyse ved, at samspillet bevæger sig i retning af i højere grad at være et emnenetværk, hvor den enkelte aktør har svært ved at kontrollere slutproduktet af processen.

I 2004 er DIF som organisation således ikke i samme grad dominerende på den idrætspolitiske slagmark. Samspillet mellem stat og interesseorganisationer har i 2004 træk, der minder om et emnenetværk, hvilket indikerer, at DIF ikke i samme grad kontrollerer policy-outcome.

TD har frem til 2004 tilkæmpet sig en central placering inden for eliteidrætten. Men alligevel formåede DIF at spille en række stærke kort ud i løbet af lovgivningsprocessen. Men en væsentlig ændring i lovgivningsprocessen er, at DIF ikke længere har noget, der minder om monopol på at repræsentere eliteidrætsudøvere. TD har stort set overtaget den rolle, hvorfor DIF ikke længere kan tilbyde staten den ressource. Dermed svækkes politikfællesskabet, der dominerede lovgivningsprocessen i forbindelse med den gamle eliteidrætslovs vedtagelse.

Et forstyrrende element var naturligvis, at syv af de største specialforbund udtalte deres støtte til TD og dermed svækkede DIF på ressourcedimensionen, men der er måske god grund til ikke at undervurdere, hvad DIF fik ud af processen. Repræsentantskabets afskaffelse var en attraktiv løsning for DIF, idet man ikke kunne vide sig sikker på, at repræsentantskabet ville give tilsvarende indflydelse i bestyrelsen.

Dertil kommer, at DIF i fællesskab med ministeren er ansvarlig for, at der er en hensigtsmæssig sammensætning af kompetencer i bestyrelsen for TD; herunder at 
såvel trænere som aktive er repræsenteret. I forbindelse med den første konstituering af bestyrelsen udpegede ministeren en træner og en aktiv, hvorfor DIF fik mulighed for at udnævne fire til bestyrelsen uden hensyntagen til, at de skulle være hverken trænere eller aktive. ${ }^{30}$

Det er bemærkelsesværdigt, i hvor høj grad der har været enighed om substansen $\mathrm{i}$ lovforslaget både i 1984 og 2004. På det overordnede plan var der enighed om, at vilkårene for eliteidræt $\mathrm{i}$ begge tilfælde havde ændret sig, og at det var nødvendigt at tilpasse lovgivningen til disse ændringer. Såvel i 1984 som 2004 fulgte staten således de indstillinger, der kom ud af diverse udvalg. Men særligt i 2004 brød magtkampene for alvor løs, når det skulle besluttes, hvordan TD fremover skulle styres.

TD har haft en god sag, idet der har været tilfredshed med deres arbejde fra såvel udøvere som specialforbund. Det har gjort det svært for såvel kulturministeren som Kai Holm at argumentere for, at TD skulle forandres. TD har i den forbindelse uden tvivl haft et stærkt kort i TD Træner-Aktiv gruppens udbredte støtte. Men til gengæld bør TD's rolle i medierne heller ikke undervurderes. Når de største specialforbund, trænere og aktive samstemmende taler for en bevarelse af TD, ville det have karakter af et politisk selvmål, hvis Brian Mikkelsen i forlængelse af en sådan aftale nedlagde organisationen.

Dette hænger sammen med, at mediernes rolle har ændret sig over tid. Medierne er i dag aktive med- og modspillere i forhold til politikerne. Hverken interesseorganisationer eller politikere er i stand til at styre, hvilke sager medierne behandler. Medierne har deres egen dagsorden, hvor nyheder udvælges på baggrund af specifikke kriterier. Et kriterium er, at historien kan vinkles med fokus på konflikt. Endvidere er det godt, hvis en svag part står over for en væsentlig stærkere part - en »Davids kamp mod Goliath «. ${ }^{31}$ En oplagt vinkling på eliteidrætsloven synes netop at være at fokusere på striden mellem DIF og Kulturministeriet på den ene side (Goliath) over for TD's Træner-Aktiv gruppe (David) på den anden side. En indtænkning af mediernes rolle som en selvstændig aktør ville således yderligere styrke Rhodes netværkstilgang. Teoriens forklaringskraft i forbindelse med eliteidrætslovgivningens vedtagelse i 1984 og 2004 ville derfor have været større, hvis også mediernes rolle havde været inddraget.

\section{Noter}

1. Lovtidende (1984), Nr. 643.

2. Ministerielt arkivalie: L136.

3. Policy er det engelske udtryk for politikkens indhold, mens politics henviser til politiske processer og handlinger, og polity er det politiske system (Andersen, 1998, s. 11). Vi beskæftiger os her med politikkens indhold - med policy. For mere om Parsons opfattelse af policyprocessens faser se Parsons (1995), s. 77.

4. Egen oversættelse af Rhodes (1997), s. 44.

5. Daugbjerg og Blom-Hansen (1999), s. 13ff.
6. Kulturministeriet (2001), s. 18/Ibsen (1996), s. 119-120

7. Kulturministeriet (1983).

8. Kulturministeriet (2001), s. 18-20.

9. I forskningen er der en del uenighed om, hvem der var primus motor i nedsættelsen. Bjarne Ibsen peger på, at det var et oplæg fra Danmarks Olympiske Komite (DOK), mens Krarup og Eggert argumenterer for, at det var DIF, der skabte stemningen for nedsættelsen af et udvalg. Løvstrup kommer i sit speciale fra 2001 frem til en hel tred- 
je aktør, som kun implicit repræsenterer en organisation; nemlig ministersekretær i Kulturministeriet Claus Bøje, der tidligere repræsenterede de aktive udøvere og syntes at have sympati for deres interesser. (Ibsen (1996), s. 120; Krarup og Eggert (1999), s. 102; Løvstrup \& Hansen (2002), s. 5764).

10. De aktive udøvere var i 1970'erne og 1980'erne organiseret i bevægelsen Dansk Aktiv Gruppe. Denne gruppe benævnes herefter som 'de aktive' (Løvstrup \& Hansen (2002), s.58ff).

11. Eksempelvis indeholdt betænkningen en delvis statsstyring af Dantop og et opgør med enhedsideologien - det vil side den opfattelse, at eliteidrætten og breddeidrætten hænger sammen. (Løvstrup \& Hansen (2002), s. 15, 79ff).

12. Krarup og Eggert (1999), s. 103.

13. Blom-Hansen (1999), s. 15.

14. Berlingske Tidende (21/6 1999); Ekstra Bladet (01/02 2001).

15. Ekstra Bladet (31/1 2001).

16. Løvstrup \& Hansen (2002), s. 127.

17. Kulturministeriet (2003), s. 13.

18. Undtagelsen er, at DGI ikke er med - men DGI berøres stort set ikke af eliteidrætslovgivningen og har allerede tidligt i forløbet udtalt, at de går ind for, at TD lægges ind under DIF (Jyllands-Posten 12/9 2002).

19. Eksempelvis forsøger KL at melde sig på banen i forbindelse med Kulturudvalgets høringsrunde, men deres henvendelse fører ikke til nogen ændringer i lovgrundlaget (Ministerielle arkivalier: L136).

20. Idrætsliv (2003), nr. 5.

21. Her tænker vi primært på DIF's Kai Holm, TD's Preben Kragelund og Kulturministeren.

22. Idrætsliv (2002), nr. 3 og TD-aktuelt (februar, 2003).

23. KPMG (2002).

24. Jyllands-Posten, 5/5 2002, 6/5 2002, 29/9 2003 / Politiken 13/10 2002.

25. Klimaet mellem parterne synes i det hele taget at blive voldsomt forværret, efterhånden som KPMG analysen fremlægges. TD afviser sammen med professor Klaus Nielsen fra Roskilde Universitetscenter rapporten som et partsindlæg, og TD kommer med skarpe udfald mod DIF generelt og i særdeleshed mod Kai Holm (Politiken 4/5 2003, Jyllands-Posten 5/5 2002, Jyllandsposten, 6/5 2002).

26. Eksempelvis var de nødt til at hente juridisk bistand i forbindelse med et høringssvar til kulturudvalget (Ministerielt arkivalie: L136).

27. Ministerielt arkivalie: L136.

28. Jyllands-Posten (d. 25/10 2003).

29. Ministerielt arkivalie: L136.

30. Berlingske Tidende (21/3 2004 ).

31. Andersen m. fl. (2004), s. 223f/Pedersen (2000), s. 210-211.

\section{Litteraturliste}

Andersen, JG. Politik og samfund i forandring - bind 1 (København, 1998).

Andersen, JG, Togeby, L, Christiansen, PM, Jørgensen, TB \& Vallgårda, S. Magt \& demokrati i Danmark - Hovedresultater fra Magtrudredningen (Aarhus, 2004).

Daugbjerg, C \& Hansen, JB., Magtens organisering (Gylling, 1999).

Ibsen, B. Det offentlige \& idratten. I Trangbæk, E. (Red), Dansk Idrætsliv (Bd. 2), s. 111-130 (Viborg, 1996).

Hansen, J \& Løvstrup I.. Da eliteidratten blev stueren (Gylling, 2002).

Løvstrup, I. Da Eliteidratten blev stueren (Odense, 2001).

KPMG. Sammenfatning af analysen om Eliteidrat (København, 2002).
Krarup, J \& Eggert, A.. Idratspolitik: Institutioner og indflydelse (Århus, 1999).

Kulturministeriets Eliteudvalg. Eliteidratsudфveres vilkår (København, 1983).

Kulturministeriet. Eliteidraet i Danmark - Rapport af den af kulturministeren nedsatte arbejdsgruppe vedrørende loven om eliteidrattens fremme ( $\mathrm{K} \varnothing$ benhavn, 2001).

Kulturministeriet. Dansk eliteidrat - Udvikling og fremtidsperspektiver (København, 2003).

Pedersen, OK. Politisk journalistik (Århus, 2000).

Parsons, W. Public policy (1995).

Rhodes RAW. Understanding governance: Policy networks, governance, reflexivity and accountability (Buckingham, 1997).

TD-aktuelt (februar 2003). 
Avisartikler

Diverse avisartikler fra Mandag Morgen, Berlingske Tidende, Ekstra Bladet, Politiken \& Jyllands-Posten.

\section{Tidsskrifter}

Bang, S \& Hansen, M.M. Tanker fra fortiden. Trykt $i$ Idratsliv (2001), nr.3.

Bang, S. DIF kalder til forsoningsm $\phi$ de. Trykt i Idratsliv (2002), s.11.

Hansen, M.M. Nyt elitesamarbejde på vej. Trykt i Idratsliv (2002), nr.3 .
Holm, Kai Eliteudfordringen. Trykt i Idratsliv (2003), nr.5.

Ministerielle arkivalier

Lovtidende. Lov om eliteidrattens fremme. Afdeling A, Bind 3, Nr. 643 (1984).

Kulturudvalgets behandling af L136 vedr. Eliteidrætsloven (2004). Hentet fra www.ft.dk.

Behandling af lovforslag nr. L 136: Forslag til lov om eliteidræt (2004). Hentet fra www.ft.dk.

Forslag L136, »Forslag til Lov om Eliteidrat« (2004). 